\title{
OPTIMIZATION OF THE SURIMI PRODUCTION FROM MECHANICALLY RECOVERED FISH MEAT (MRFM) USING RESPONSE SURFACE METHODOLOGY
}

\author{
FABÍOLA H S. FOGAÇA ${ }^{1,2}$, LUZIA APARECIDA TRINCA ${ }^{3}$ and ÁUREA JULIANA BOMBO ${ }^{4}$ and \\ LÉA SILVIA SANT'ANA ${ }^{2,5}$ \\ ${ }^{1}$ Embrapa Meio-Norte, Parnaíba, PI \\ UNESP, Centro de Aqüicultura da UNESP, Via de Acesso Prof. Paulo Donato Castellane, s/n, 14884-900, Jaboticabal, SP \\ ${ }^{3}$ Instituto de Biociências de Botucatu, UNESP, Botucatu, SP \\ ${ }^{4}$ Departamento de Nutrição, USP, Faculdade de Saúde Pública, São Paulo, SP
}

${ }^{5}$ Corresponding author.

TEL: +55-14-38807642;

FAX: +55-14-38807164;

EMAIL: santana@fca.unesp.br

Received for Publication June 12, 2012

Accepted for Publication January 2, 2013

$10.1111 /$ jfq. 12019

\begin{abstract}
The by-products generated from industrial filleting of tilapia surimi can be used for the manufacture of surimi. The surimi production uses large amounts of water, which generates a wastewater rich in organic compounds (lipids, soluble proteins and blood). Optimizing the number of washing cycles will contribute to a more sustainable production. A mathematical model of mechanically recovered tilapia meat (Oreochromis niloticus) for the processing of surimi (minced fish washing cycles and tapioca starch addition) based on two quality parameters (texture and moisture) was constructed by applying the response surface methodology (RSM). Each factor had an important effect on the moisture and texture of surimi. This study found that the optimal formulation for producing the best surimi using the by-products of tilapia filleting in manufacturing fish burger were the addition of $10 \%$ tapioca starch and three minced fish washing cycles. A microstructural evaluation supported the findings of the mathematical model.
\end{abstract}

\section{PRACTICAL APPLICATIONS}

The use of mechanically recovered fish meat (MRFM) for the production of surimi enables the utilization of the by-products of filleting fish. However, the inferior quality of the surimi produced from MRFM in relation to that produced with fillets necessitates the addition of starch; secondly, surimi production consumes a large volume of water. RSM provides a valuable means for optimizing the number of washing cycles and starch amounts utilized in fish burger production. Tapioca starch, widely produced in Brazil, has desirable characteristics (surface sheen, smooth texture, neutral taste and clarity in solution) for use in MRFMproduced surimi.

\section{INTRODUCTION}

In 2010, the tilapia was responsible for $40 \%$ of aquaculture production of freshwater fish in Brazil (FAO 2012), and that most of the tilapias were used to produce fillet. The average tilapia fillet yield varies from $30-38 \%$ and industrial filleting generates significant amounts of by-products. The development of technology for protein recovery from filleting by-products offers many benefits, because this technol- ogy facilitates the more responsible utilization of available resources for human food and it reduces the environmental stresses associated with the disposal of processing by-products (Jaczynski 2005). The recovered muscle protein can be used to manufacture value-added products such as surimi.

Surimi is minced fish flesh that has been washed to remove most of the lipids, blood, enzymes and sarcoplasmic proteins, which is then stabilized using cryoprotectants to 
allow frozen storage (Lee 1984; Park and Lin 2005; Julavittayanukul et al. 2006).

The utilization of fish industry by-products, such as surimi, provides an important opportunity for the industry because it could potentially generate additional revenue as well as reducing the costs of disposing of these materials (UNEP 2000). However, surimi requires the use of large volumes of freshwater and it produces high levels of contaminated wastewater (Martín-Sánchez et al. 2009).

The number of washing cycles, the ratio of water: fish, and the washing time are important factors determining the quality of surimi gel. The amount of water required and the number of washing cycles is determined by the fish species, the fish condition and the product quality required (Lee 1984).

The texture, color and odor composition of the final product is greatly improved when impurities are removed by washing (Park and Lin 2005). These functional properties are the major factors responsible for the final acceptance of surimi-based products by consumers (Tabilo-Munizaga and Barbosa-Canóvas 2004; Park and Morrissey 2005). However, rising utility costs, limited water sources and pollution have prompted surimi manufacturers to consider minimizing water usage and reducing wastewater disposal (Park and Lin 2005). The number of washing cycles and ratio water : fish are important parameter for texture, color and odor, and the use of mechanically recovered meat usually requires a larger amount of water.

Starches promote the formation of a continuous matrix by interacting with water and protein in the fish paste and they have an important role in improving the mechanical and functional properties of surimi (Ramirez et al. 2011). Furthermore, starch is added to surimi to maintain gel strength with a reduction in surimi content, because of its water-binding ability, while it also improve stability during refrigerated or frozen storage (Lee 1984). A 4-12\% starch level is commonly added to surimi and the most frequently used starches include wheat, corn, potato, waxy maize and tapioca (starch produced from treated and dried cassava root) (Hunt et al. 2010). Different botanical starch sources have different effects on the texture of surimi starch gels (Yang and Park 1998). In Brazil, tapioca starch is widely used in the baking industry because of its special characteristics in starch gelatinization and the added advantage of not containing gluten. Tapioca starch is used in meat industry for its surface sheen, smooth texture, neutral taste and clarity in solution (Zhang and Barbut 2005). The cassava plant originated in the Brazilian Amazon rainforest and it was adopted as a staple food in the African and Asian continents, which are now the main producers of this raw material (Maieves et al. 2011).

Response surface methodology (RSM) is a useful statistical technique that has been applied to complex variable processes where its principal advantage is the reduced number of experimental runs required to generate sufficient information to provide a statistically acceptable result (Jeong et al. 2009).

The present study tested the number of washing cycles and the starch concentration as independent variables when optimizing shear stress and moisture in tilapia surimi for fish burger production.

\section{MATERIALS AND METHODS}

\section{Materials}

Experiments were performed at Universidade Estadual Paulista, UNESP, Brazil. Minced fish of tilapia was obtained from a commercial abattoir. The meat was removed from tilapia carcasses that were produced and slaughtered at the site and that belonged to the same production lot. Fish were deprived of food for $24 \mathrm{~h}$ and then killed by heat shock (using water and ice at a 1:1 ratio), before gutting and heading prior to fillet removal. Once sliced, the fish carcasses were passed through a deboning machine (High Tech, HT 250, Chapeco, SC, Brazil) to remove muscle attached to bones, resulting in a product known as mechanically recovered fish meat (MRFM). The MRFM was packaged and frozen in a freezing tunnel at $-25 \mathrm{C}$ and then stored in a freezer at $-18 \mathrm{C}$. Samples were transported in cold boxes to keep them frozen. On arrival at the laboratory, they were kept in a freezer $(-18 \mathrm{C})$ for $48 \mathrm{~h}$.

\section{Surimi Preparation}

Surimi was prepared using a manual process. The MRFM was kept under refrigeration at $5 \mathrm{C}$ for $24 \mathrm{~h}$ before being handled. After thawing, it was subjected to a different number of washing steps (1,3 or 5) using four volumes of cold distilled water. The water temperature during washing was maintained at approximately 5C using crushed ice. After each wash, the mince was manually pressed on cotton. At the end of processing, 1\% sucrose was added as a primary cryoprotectant and $2 \%$ sodium chloride was used as a flavor enhancer, which masked the sweetness, because Brazilians dislike surimi-based products with strong sweet taste. The treatment with 10 or $20 \%$ of starch addition was done slowly until homogenization. Adding starch was performed to simulate the fish burger production according Fogaça (2009). The addition of cryoprotectants (sucrose), flavor enhancer (sodium chloride) and texture enhancer (starch) was performed using an electric mixer (Arno, Planetaria, São Paulo, Brazil), then surimi was frozen.

\section{Surimi Gel Preparation}

Surimi samples were thawed and placed in ham forms during baking and the induction of surimi gelatinization. 
Each sample was directly cooked to a gel in a bath (Novatecnica, NT 249, Piracicaba, SP, Brazil) and heated at 90C for $30 \mathrm{~min}$. After cooking, samples were cooled using crushed ice for $15 \mathrm{~min}$ to stop the process.

\section{Shear Stress}

The shear stress of fish ham was measured using an SMS TA-XT PlusTexture Analyzer (Stable Micro Systems, UK) and blade attachment (Warner-Bratzler shearing device) with a load cell of $5 \mathrm{~kg}$ and a crosshead speed of $12 \mathrm{~cm} / \mathrm{min}$ at a distance of $1.5 \mathrm{~cm}$. Cubes $\left(1 \mathrm{~cm}^{3}\right)$ were compressed in the axial direction until they completely cut the sample. The computer program Texture Expert Exceed version 2.5 was used for data collection (25 measurements per treatment) and shear stress calculation (expressed in $\mathrm{KPa}$ ). Shear stress was carried out at room temperature (20-22C).

\section{Moisture}

The moisture content was determined based on the weight difference of $2 \mathrm{~g}$ surimi before and after heating in an oven (Fanen, São Paulo, Brazil) for 24 h at 105C (method 950.46) (Association of Official Analytical Chemists 2005). All samples were stored at $-18 \mathrm{C}$ and thawed at $5 \mathrm{C}$ for a period of $24 \mathrm{~h}$ prior to analysis.

\section{Scanning Electron Microscopy (SEM)}

The microstructure of gels prepared using the different methods was determined with a SEM. Samples with a thick- ness of $5 \mathrm{~mm}$ were fixed using $2.5 \%$ buffered glutaraldehyde and post-fixed in $1 \%$ osmium tetroxide for $2 \mathrm{~h}$. They were then washed in phosphate buffered saline, dehydrated in ethanol and dried to the critical point using $\mathrm{CO}_{2}$. Samples were metalized with pale-gold ions prior to electron micrography.

\section{Design and Statistical Analysis}

The experimental design was a three-level Central Composite Design (Box and Draper 1987) that included 18 runs divided into two blocks at each time (Table 1). The central point was replicated six times (five within a block) and the two-level factorial portion was replicated twice. The responses were analyzed by fitting RSMs (second order polynomials) after coding both factors, i.e., washing cycles $\left(\mathrm{x}_{1}\right)$ and starch amount $\left(\mathrm{x}_{2}\right)$, such that their levels were centered at zero and their maximum and minimum levels were 1 and -1 , respectively. The " $\mathrm{lm}$ " function from R (R Development Core Team 2011) was used for the calculations. $F$-tests from the analysis of variance were used for deciding for parsimonious fitted models following the hierarchy principle applied to the polynomial terms (Wu and Hamada 2009). Significance was attained for $P$-value smaller than 0.05 .

\section{RESULTS}

In the analysis of the response variable moisture, the analysis of variance and associated $F$-tests for model effects indicated significant linear effects of the number of washing
TABLE 1. EXPERIMENTAL DESIGN $\left(X_{1}, X_{2}\right)$, MOISTURE (M) AND SHEAR FORCE (SF) ACCORDING TO THE NUMBER OF SAMPLE WASHINGS (W) AND THE PROPORTION OF ADDED CASSAVA STARCH (S)

\begin{tabular}{|c|c|c|c|c|c|c|}
\hline Treatment* & $x_{1}=\frac{W-3}{2}$ & W & $x_{2}=\frac{S-10}{10}$ & $\mathrm{~S}(\%)$ & $\begin{array}{l}\mathrm{y}_{1} \\
\mathrm{M}(\%) \dagger\end{array}$ & $\begin{array}{l}\mathrm{y}_{2} \\
\mathrm{SF}(\mathrm{KPa}) \dagger\end{array}$ \\
\hline W1s0 & -1 & 1 & -1 & 0 & $75.24(0.43)$ & $32.5(5.9)$ \\
\hline W1S20 & -1 & 1 & 1 & 20 & $65.14(0.20)$ & $32.0(5.7)$ \\
\hline W5SO & 1 & 5 & -1 & 0 & $83.24(0.18)$ & $43.0(11.6)$ \\
\hline W5S20 & 1 & 5 & 1 & 20 & $71.86(0.14)$ & $42.4(15.7)$ \\
\hline W3S10 & 0 & 3 & 0 & 10 & $72.07(0.27)$ & $17.1(5.5)$ \\
\hline W3S10 & 0 & 3 & 0 & 10 & $78.54(0.65)$ & $22.4(10.2)$ \\
\hline W3S10 & 0 & 3 & 0 & 10 & $72.51(0.89)$ & $15.0(5.6)$ \\
\hline W3S10 & 0 & 3 & 0 & 10 & $72.38(0.20)$ & $16.3(6.4)$ \\
\hline W3S10 & 0 & 3 & 0 & 10 & $74.79(0.36)$ & $14.4(5.6)$ \\
\hline W1S0 & -1 & 1 & -1 & 0 & $72.61(0.30)$ & $18.0(6.9)$ \\
\hline W1S20 & -1 & 1 & 1 & 20 & $64.57(0.88)$ & $16.6(4.1)$ \\
\hline W5SO & 1 & 5 & -1 & 0 & $78.88(0.61)$ & $24.7(10.3)$ \\
\hline W5S20 & 1 & 5 & 1 & 20 & $71.20(0.93)$ & $17.9(5.3)$ \\
\hline W3S10 & 0 & 3 & 0 & 10 & $68.53(1.66)$ & $18.0(3.7)$ \\
\hline W1S10 & -1 & 1 & 0 & 10 & $69.31(0.69)$ & $11.5(2.1)$ \\
\hline W5S10 & 1 & 5 & 0 & 10 & $75.70(0.29)$ & $11.0(1.0)$ \\
\hline W3So & 0 & 3 & -1 & 0 & $75.44(0.97)$ & $11.4(1.7)$ \\
\hline W3S20 & 0 & 3 & 1 & 20 & $66.84(0.09)$ & $20.1(2.9)$ \\
\hline
\end{tabular}

* Does not correspond to the randomized order.

+ Mean (standard deviation). We used 25 readings for texture $(n=25)$ and four moisture analyses in triplicate $(n=12)$ per test. 
TABLE 2. SECOND ORDER MODEL PARAMETER ESTIMATES FOR MOISTURE $\left(R^{2}=0.89\right)$

\begin{tabular}{lcl}
\hline Parameter & Estimate & $\begin{array}{l}\text { Standard } \\
\text { error }\end{array}$ \\
\hline Intercept & 71.09 & 1.00 \\
Block effect & 2.64 & 0.97 \\
$x_{1}$ & 3.40 & 0.63 \\
$x_{2}$ & -4.58 & 0.63 \\
$x_{1}^{2}$ & 0.96 & 1.14 \\
$x_{2}^{2}$ & -0.41 & 1.14 \\
$x_{1} \cdot x_{2}$ & -0.12 & 0.70 \\
\hline
\end{tabular}

cycles $(P$-value $=0.0002)$ and starch content $(P$-value $<0.0001)$. There was no evidence of curvatures with respect to both factors or any interaction between them ( $P$-values $=0.4606,0.7272$ and 0.87334 , respectively $)$. Parameter estimates and their standard errors are presented in Table 2. The fitted equation, averaging over the two blocks, resulted in: $\hat{y}_{1}=72.41+3.40 x_{1}-4.58 x_{2}$, where $\hat{y}_{1}$ is the fitted response moisture. The fitted model indicated that moisture increases with washing cycles and decreases with starch addition (as expected). The contours and plane surface for the fitted response moisture are shown in the first row of Fig. 1. The estimates show that any level of moisture between 65 and $80 \%$ can be obtained by varying the starch level and the number of washing cycles. Moisture levels between 75 and $78 \%$ can be achieved by reducing the starch level if the number of cycles is low or vice-versa.

Analysis of variance for the response shear stress showed strong evidence of curvature effects for both washing cycles $(P$-value $=0.0026)$ and starch $(P$-value $=0.0108)$ factors. Again, there was no evidence of interaction between the two factors $(P$-value $=0.7406)$. Parameter estimates and standard errors are presented in Table 3 . The fitted equation, averaged over the two blocks, resulted in: $\hat{y}_{2}=12.70+2.84 x_{1}-0.06 x_{2}+5.53 x_{1}^{2}+10.03 x_{2}^{2}$, where $\hat{y}_{2}$ is the fitted response shear stress. Contours and surfaces for the estimated response are shown in the second row of Fig. 1. A region of minimum response can be seen from

TABLE 3. SECOND ORDER MODEL PARAMETER ESTIMATES FOR SHEAR STRESS $\left(R^{2}=0.78\right)$

\begin{tabular}{lcl}
\hline Parameter & Estimate & $\begin{array}{l}\text { Standard } \\
\text { error }\end{array}$ \\
\hline Intercept & 6.20 & 2.85 \\
Block effect & 13.00 & 2.79 \\
$\mathrm{x}_{1}$ & 2.84 & 1.81 \\
$\mathrm{x}_{2}$ & -0.06 & 1.81 \\
$\mathrm{x}_{1}^{2}$ & 5.53 & 3.28 \\
$\mathrm{x}_{2}^{2}$ & 10.03 & 3.28 \\
$\mathrm{x}_{1} . \mathrm{x}_{2}$ & -0.69 & 2.04 \\
\hline
\end{tabular}

these plots and the partial derivatives of the shear stress with respect to washing cycles and starch addition indicated that the estimated shear stress attained the minimum when starch amount was around 10 and washing cycles around 2.5 which means in practice, two or three cycles.

In accordance with the model in optimum conditions for tilapia surimi production, the shear force predicted is $12.5 \mathrm{KPa}$ while in practice conditions, using three washing cycles, the shear force determined is $17.2 \pm 2.86 \mathrm{KPa}$.

The highest values for shear stress were observed with 0 and $20 \%$ starch and one or five washing cycles. The protein structure of surimi with $0 \%$ starch and one washing cycle was intact and the fat droplets remained within the protein network (Fig. 2A). The protein structure was surrounded by starch granules while the fat droplets appeared to be wrapped in starch granules $(20 \%$ starch and one washing cycle) (Fig. 2B). With five washing cycles, $0 \%$ starch it was found that the protein structure contained gaps, probably due to changes in protein composition and the elimination of soluble proteins, which consequently increased the concentration of myofibrillar proteins (Fig. 2C), while with five washing cycles, $20 \%$ starch that the structure was now formed of a mass of protein, starch and fat droplets (Fig. 2D).

The surimi gel produced with $10 \%$ starch and three washing cycles had an intermediate structure with amorphous starch granules that were probably gelatinized, while the fat droplets were evenly distributed throughout the surimi structure (Fig. 3).

\section{DISCUSSION}

Since the surimi produced in this study was to be used for fish burger production, it was desirable that the product had a soft texture with a low shear force. Burgers formulated from blends, in particular tapioca starch, present improved tenderness and in particular lowered shear force (Troy et al. 1999). Based on these considerations, we estimated that the shear stress was minimized when the starch amount was approximately $10 \%$ with approximately 2.5 washing cycles, which in practice meant three cycles (Fig. 1, second row). A micrograph of this treatment (Fig. 3) shows that the presence of fat globules and a starch network surrounded by the protein matrix promoted the soft texture.

The use of three washing cycles during the preparing of surimi from tilapia fillets, with a fish-to-water ratio of $1: 4(\mathrm{w} / \mathrm{v})$ or $1: 3(\mathrm{w} / \mathrm{v})$, is recommended by several authors (Rawdkuen et al. 2009; Duangmal and Taluengphol 2010; Ingadottir and Kristinsson 2010; Mahawanich et al. 2010).

The addition of starch can enhance the textural characteristics of breaded or restructured products made with surimi. There is an increasing interest in identifying 

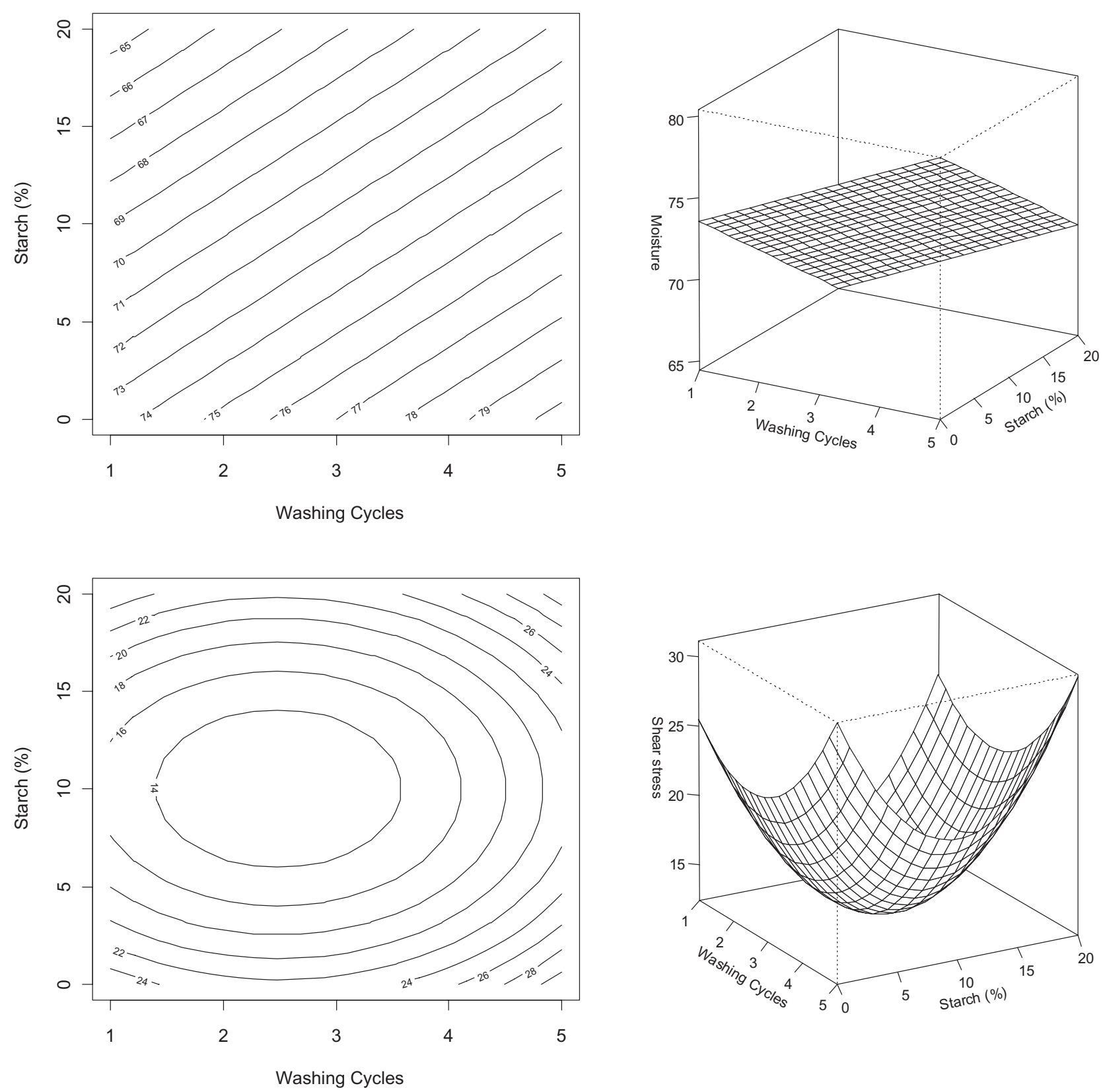

FIG. 1. FITTED CONTOURS AND SURFACES FOR THE RESPONSE VARIABLES MOISTURE (FIRST ROW) AND SHEAR STRESS (SECOND ROW)

novel applications for both native and modified starches to improve the mechanical and functional properties of surimi products (Ramirez et al. 2011). In spite of their higher amylose content, about $18 \%$, tapioca starches give relatively stable, clear sols on cooling, because this amylose is higher in molecular weight and may be more branched than other starches (Mason 2009). Furthermore, the addition of salt helps to disperse the fish proteins in the tapioca starch system (Chow and Yu 1997).
The U.S. Department of Agriculture has also authorized the use of a Commercial Item Description, for surimi products, whose analytical requirements specify that starch should constitute no more than $10 \%$ of the total (USDA 2008). The relevant Brazilian law, drafted by the Ministry of Agriculture, Livestock and Supply, states that breaded products can possess 30\% carbohydrates and at least $10 \%$ protein (Brasil 2012). Thus, the amount of tapioca starch in the optimum condition meets both laws. 


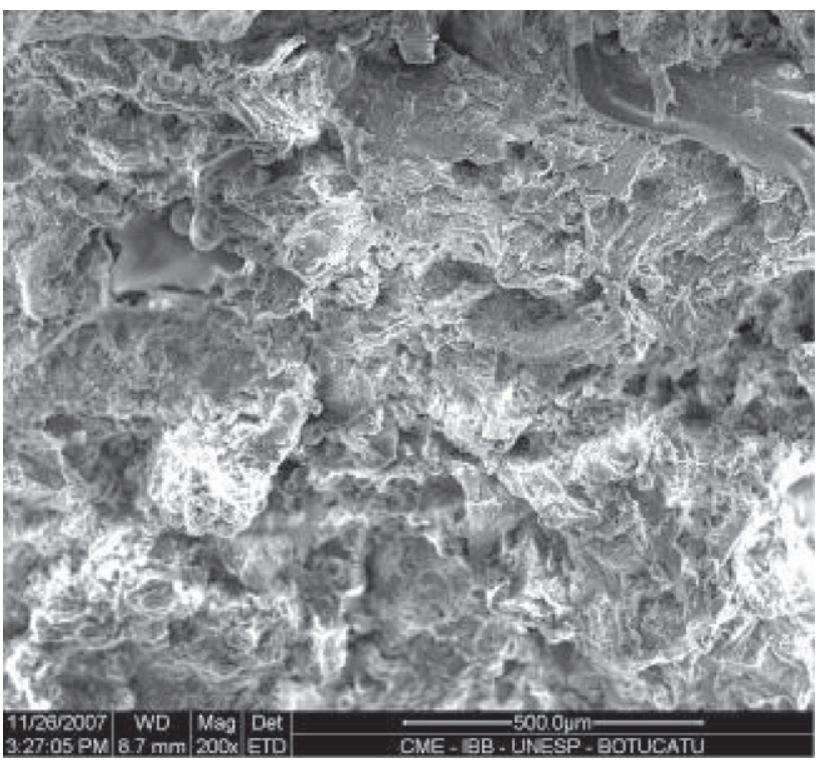

A $0 \%$ Starch, one washing cycles

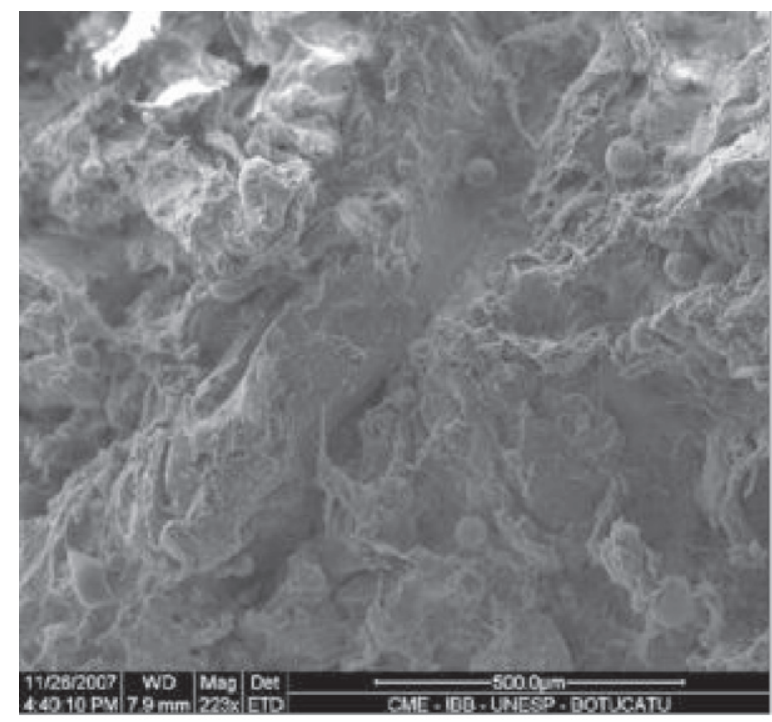

C $0 \%$ Starch, five washing cycles

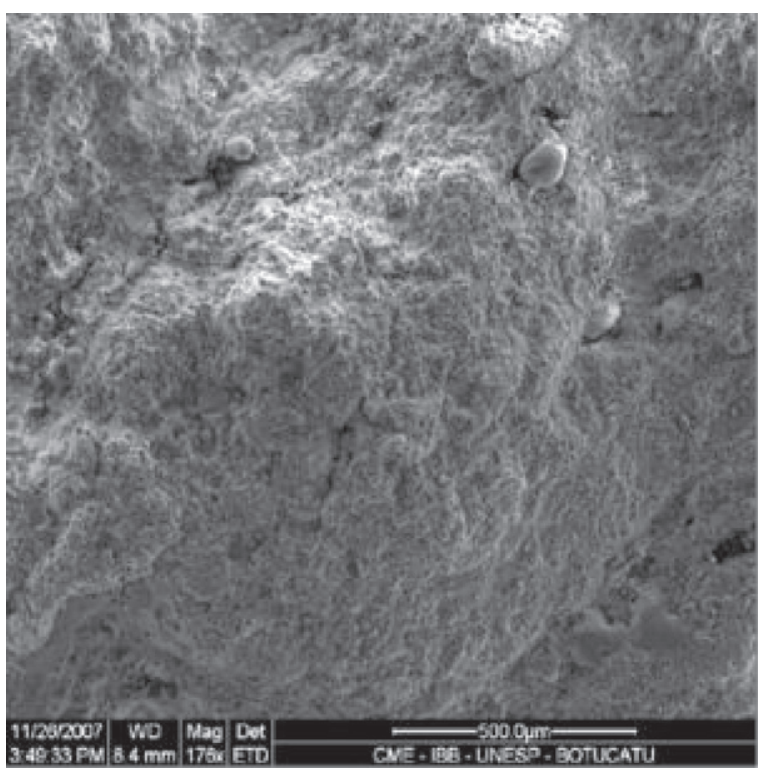

B $20 \%$ Starch, one washing cycles

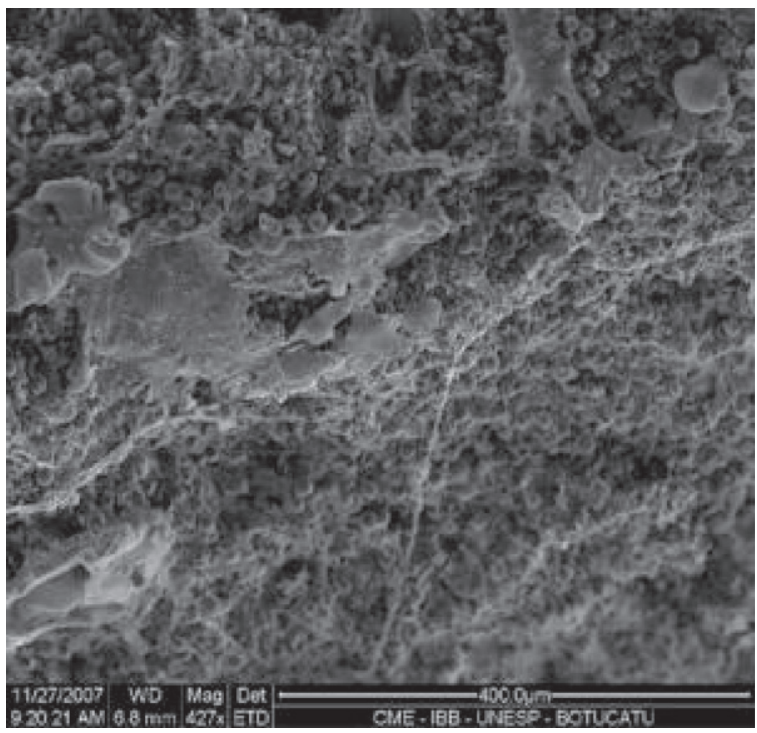

D $20 \%$ Starch, five washing cycles

FIG. 2. MICROSTRUCTURE OF TILAPIA SURIMI GEL WITH O OR 20\% STARCH AND ONE OR FIVE WASHING CYCLES

\section{CONCLUSIONS}

The optimizing process will contribute to sustainable production of tilapia surimi, by utilizing filleting by-products in the preparation of restructured products with high biological value, such as the fish burger and by reducing the amount of water wasted with excessive washings. The optimal conditions for tilapia surimi made with MRFM were the addition of $10 \%$ tapioca starch and three washing cycles. Further studies are needed to determine the optimum quantity of water used for washing (the water-tofish ratio) in each cycle.

\section{ACKNOWLEDGMENTS}

This paper was based on the work funded by Fundação de Amparo a Pesquisa do Estado de São Paulo (FAPESP), Brazil, (2006/06388-7). 


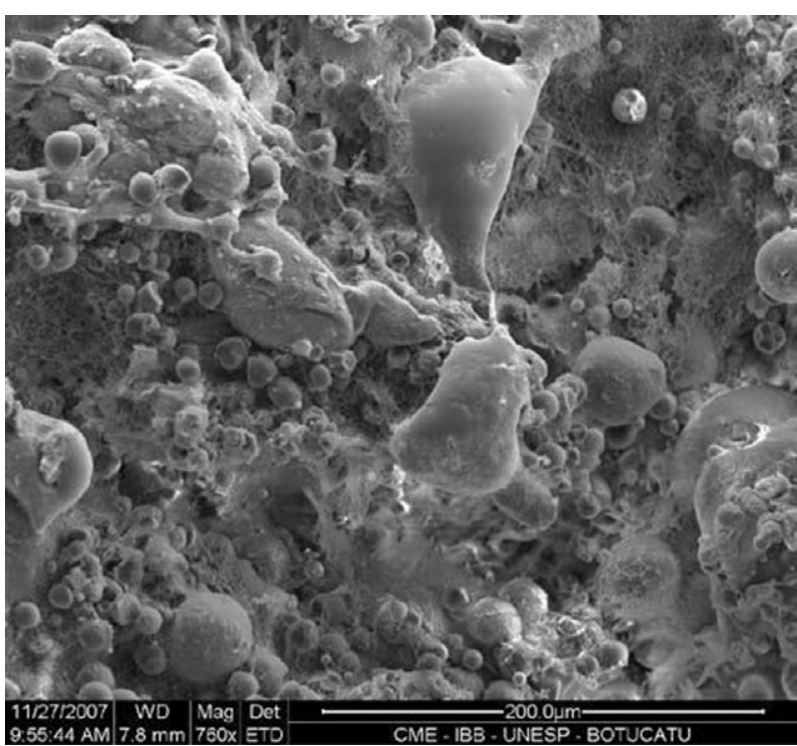

FIG. 3. MICROSTRUCTURE OF TILAPIA SURIMI GEL WITH 10\% STARCH AND THREE WASHING CYCLES

\section{REFERENCES}

ASSOCIATION OF OFFICIAL ANALYTICAL CHEMISTS. 2005. Official Methods of Analysis of the Association of Official Analytical Chemists, 18th Ed., Association of Analytical Chemists, Gaithersburg, MD.

BOX, G.E.P. and DRAPER, N.R. 1987. Empirical Model-Building and Response Surfaces, pp. 304-326, John Willey \& Sons, New York, NY.

BRASIL. 2012. Instrução Normativa ${ }^{\circ} 6$ de 15 de fevereiro de 2001. Ministério da Agricultura Pecuária e Abastecimento. http://extranet.agricultura.gov.br/sislegis-consulta/ consultarLegislacao.do? operacao $=$ visualizar\&id $=2198$ (accessed July 1, 2012).

CHOW, C.S. and YU, S.S. 1997. Effect of fish protein, salt, sugar, and monosodium glutamate on the gelatinization of starch in fish-starch mixtures. J. Food Process. Preserv. 21, 161-177.

DUANGMAL, K. and TALUENGPHOL, A. 2010. Effect of protein additives, sodium ascorbate, and microbial transglutaminase on the texture and colour of red tilapia surimi gel. Int. J. Food Sci.Technol. 45, 48-50.

FAO. 2012. Global Aquaculture Production. http://www.fao.org/ fishery/statistics/global-aquaculture-production/en (accessed July 2, 2012).

FOGAÇA, F.H.S. 2009. Caracterização do surimi de tilápia do Nilo: morfologia e propriedades físicas, químicas e sensoriais. PhD Thesis, Aquicultura, CAUNESP, São Paulo State, Brasil.

HUNT, A., GETTY, K.J. and PARK, J.W. 2010. Screening of special starches for use in temperature-tolerant fish proteins gels. J. Food Qual. 33, 100-118.
INGADOTTIR, B. and KRISTINSSON, H.G. 2010. Gelation of protein isolates extracted from tilapia light muscle by $\mathrm{pH}$ shift processing. Food Chem. 110, 789-798.

JACZYNSKI, J. 2005. Protein, lipid recovery from fish-processing by-products. Glob. Aquac. Advocate 8(2), 34-35.

JEONG, G.-T., YANG, H.-S. and PARK, D.H. 2009. Optimization of transesterification of animal fat ester using response surface methodology. Bioresour. Technol. 100, 25-30.

JULAVITTAYANUKUL, O., BENJAKUL, S. and VISESSANGUAN, W. 2006. Effect of phosphate compounds on gel-forming ability of surimi from bigeye snapper (Priacanthustayenus). Food Hydrocolloids 20, 1153-1163.

LEE, C.M. 1984. Surimi process technology. Food Technol. 38, 69-80.

MAHAWANICH, T., LEKHAVICHIR, J. and DUANGMAL, K. 2010. Gel properties of red tilapia surimi: Effects of setting condition, fish freshness and frozen storage. Int. J. Food Sci.Technol. 45, 1777-1786.

MAIEVES, H.A., OLIVEIRA, D.C., FRESCURA, J.R. and AMANTE, E.R. 2011. Selection of cultivars for minimization of waste and of water consumption in cassava starch production. Ind. Crops Products 32, 224-228.

MARTÍN-SÁNCHEZ, A.M., NAVARRO, C., PÉREZ-ALVAREZ, J.A. and KURI, V. 2009. Alternatives for efficient and sustainable production of surimi: A review. Comp. Rev. Food Sci. Food Saf. 8, 359-374.

MASON, W.R. 2009. Starch use in foods. In Starch, 3rd Ed., (J. Bemiller and R. Whistler, eds.) pp. 541-568, Academic Press, Burlington, NY.

PARK, J.W. and LIN, T.M.J. 2005. Surimi: Manufacturing and evaluation. In Surimi and Surimi Seafood, 2nd Ed., (J.W. Park, ed.) pp. 33-106, Taylor \& Francis Group, Boca Raton, FL.

PARK, J.W. and MORRISSEY, M.T. 2005. Manufacturing of surimi from light muscle fish. In Surimi and Surimi Seafood, 2nd Ed., (J.W. Park, ed.) pp. 23-58, Taylor \& Francis Group, Boca Raton, FL.

R DEVELOPMENT CORE TEAM. 2011. R: A Language and Environment for Statistical Computing, R Foundation for Statistical Computing, Vienna, Austria. http://www. R-project.org/ (accessed March 1, 2010).

RAMIREZ, J.A., URESTI, R.M., VELASQUEZ, G. and VÁZQUEZ, M. 2011. Food hydrocolloids as additives to improve the mechanical and functional properties of fish products: A review. Food Hydrocolloids 25, 1842-1852.

RAWDKUEN, S., SAI-UTU, S., KHAMSORN, S., CHAIJAN, M. and BENJAKUL, S. 2009. Biochemical and gelling properties of tilapia surimi and protein recovered using an acid-alkaline process. Food Chem. 112, 112-119.

TABILO-MUNIZAGA, G. and BARBOSA-CANÓVAS, G.V. 2004. Color and textural parameters of pressurized and heat-treated surimi gels as affected by potato starch and egg white. Food Res. Int. 37, 767-775. 
TROY, D.J., DESMOND, E. and BUCKLEY, D.J. 1999. Eating quality of low-fat beef burgers containing fat-replacing functional blends. J. Food Sci. Agric. 79, 507-516.

UNEP. 2000. Cleaner production assessment in fish processing, United Nations Environmental Programme (UNEP), Division of Technology, Industry and Economics, New York, NY.

USDA. 2008. Commercial Item Description: Surimi seafood products, pasteurized, refrigerated or frozen.
http://www.ams.usda.gov/AMSv1.0/getfile?dDocName= stelprdc5074005 (accessed June 20, 2012).

WU, J.H. and HAMADA, M. 2009. Experiments: Planning, Analysis and Optimization, pp. 172-176, Wiley, New York, NY.

YANG, H. and PARK, J.W. 1998. Effect of starch properties and thermal-processing condition on surimi-starch gels. Food Sci. Technol. 31, 344-353.

ZHANG, L. and BARBUT, S. 2005. Effects of regular and modified starches on cooked pale, soft, exudative; and dry, firm and dark breast meat batters. Poultry Sci. 84, 789-796. 